\title{
The Quest for Sanity in a Massachusetts Prison Charles N. Diorio
}

66 Crazy people can make you crazy", says a hard looking African American prisoner here in MCI-Shirley. "Don't use my name", I am told. His cautious words speak from nearly 37 years of experience doing time here in a Commonwealth Correctional Institution.

Here in MCI-Shirley, a distressed medium security prison camp located in eastern Massachusetts, mental illness thrives, and many say it is contagious. Prisoners suffering from mental illness litter this prison. Most live silently behind heavy steel sliders and their condition may only be discovered once it is too late.

I arrived here in MCI-Shirley in February 2014. During my time, I have witnessed conditions of confinement degrade. The physical plant is crumbling, plumbing failures leave cellblocks without hot water; prison policy changes daily; personal property is bit by bit being taken away; and prisoners are treated as little more than bodies husbanded, stalled, and fed.

Living among criminals convicted of various felonies is a fact of life in every prison worldwide. Sadly, prisons like MCI-Shirley have become default dumping grounds for surplus labour - mass incarceration - and the mentally ill. ${ }^{1}$

The melancholy result of housing mentally ill convicts alongside those confined for anti-social criminal conduct translates into unbearable misery, a misery that may violate Eighth Amendment cruelty prohibitions. ${ }^{2}$

Collateral damage from housing prisoners with the mentally ill in two man cells goes unnoticed, undocumented and often ignored entirely by prison officials. It is in the best interest of the institution to remain ignorant of the many ills confronting their general population, particularly where mental health is concerned. ${ }^{3}$

Over the past sixteen months living in MCI-Shirley, I have been assigned numerous bunkmates, some better than others. Recently, I was assigned a young man. He appears, at first blush, a well-adjusted twentythree-year-old young man, shell-shocked from trial, conviction and removal to state prison. Shortly after living together - a matter of days - he began cutting himself.

I was forced to watch the ugly transformation. The young man began cutting himself with a razor, and talking about his recent suicide attempt while he had been detained in a local county jail. I was forced to watch silently as my cellmate mutilated himself, using razors to cut his fingers, bleeding all over the cell. Refusing medical attention, his ritual for cleaning 
his blood from the cell appeared to be as important as the actual cutting. When I objected to his behaviour, we would argue. Overcome with anger and resentment, he would say, "You're a fun sucker!" I was sucking the fun from his feeling of individual autonomy. In addition to cutting himself, he pierced his body - ears, nipples, and genitals. He engaged in an elaborate ritual of enlarging the gauge, adjusting the size of each insert, which he manufactured from pieces of wet toilet paper.

Prisons are complex social institutions built on firm rules of conduct. A fundamental element of the so-called convict code is to remain silent. "Snitches get stitches", is a mantra in many state prisons. The prisoner who speaks to authorities about other prisoners is considered "a rat". I felt conflicted and bound to remain silent. As a result of our daily crises, my relationship with the young prisoner degraded to the point that we stopped speaking with each other entirely.

Fortunately, he is well known to mental health services here in Shirley; he regularly visits psychiatric services. Certain aspects of his self-mutilation - body piercing, for example - have been controlled. Medication helps him sleep at night. He is also on a waiting list for the Correction Recovery Academy, an in-house drug and alcohol treatment program offered in this facility.

The Massachusetts Department of Correction lacks a proper mental health facility and places vulnerable mentally ill prisoners among violent prisoners. ${ }^{4}$

Not every prisoner serving a prison sentence is a violent monster. Many prisoners are first time felons eager to do their time and go home. To be subjected to serving a sentence with a mentally ill prisoner may represent cruel and unusual punishment. ${ }^{5}$

Lately, every day, the general population is subjected to the spectacle of a troubled prisoner, ${ }^{6}$ a fifty-five year old prisoner who says "hello" to every prisoner he passes, addressing them by their first names. He yells his "hello's" across the prison, the dining hall and the housing unit. He seems to know the first names of all the prisoners here in MCI-Shirley. Like a parrot, he listens to conversations, gathers names and loudly pretends to know each prisoner personally. Some prisoners find it amusing, others condemn it, suspecting it violates the convict code and is disrespectful.

Overcrowded conditions exacerbate many of the problems facing this institution. Built in 1991, Shirley medium was originally designed for a maximum capacity of just 760 prisoners. Today, it is home to nearly 1200 bodies. $^{7}$ 
The loud prisoner is a fixture, a local loon, well known to prison officials. $\mathrm{He}$ is disciplined often. He is removed to segregation often. He resents having to share a cell with another person; he has attacked one celly, and has refused numerous other cell assignments. He is a frequent visitor to solitary, only to return days later to wreak further havoc.

In the 1980s a governor's panel explored the possibility of creating a comprehensive mental health centre. This proposal was never implemented. ${ }^{8}$ In 2006, the chief psychiatrist for the University of Massachusetts medical school testified that the DOC had a "dire need" for a high security residential treatment facility as an alternative to segregation for prisoners with mental illness. ${ }^{9} \mathrm{He}$ went on to say that the number of mental health clinicians was inadequate. ${ }^{10}$

A diagnosis of mental illness triggers a grotesque rollercoaster ride through the Department of Corrections. $R$. H. Mandeville v. Luis Spencer ${ }^{11}$ offers the public a vivid look at the start-to-finish process of commitment to Bridgewater State Hospital.

Mandeville sued then commissioner of the DOC, after he was diagnosed with mental illness by a clinician here in Shirley in 2009. His world was turned upside down. He was, at the time, a prisoner living in a single cell an enormous privilege in any prison.

He was made to sign commitment papers. He refused. This refusal had him removed in handcuffs to solitary confinement, today a process called "segregation". No matter how modern Corrections dresses it up, "segregation" in a "Special Management Unit" remains a solitary confinement cell in a bunker-like housing unit. Reclassified, Mandeville was eventually transferred to Old Colony Correctional Center, ${ }^{12}$ and finally to Bridgewater State Hospital. ${ }^{13}$

What escapes the public's view is the tedious horror in each step of this painful, deliberate process. Prison officials watch prisoners like him buzz around the compound, they lock them away in segregation for a variety of rule violations and medicate them. Yet, jailors do not necessarily want to be informed of a prisoner grievance or the collateral effect it may have on the general population of the institution. ${ }^{14}$

Prison officials are content to react to violence. The mechanism for writing disciplinary reports and sending prisoners to segregation is trained into each Correctional Officer. Less tangible is addressing the cause and effect of festering discontent.

Depression hangs in the air in these guarded, forbidden places. Prisoners react to the world around them, just as people in outside society 
do. When prisoners see mentally ill prisoners act out, it takes its toll on the general population.

One warm summer evening, a group of prisoners taunted the older prisoner for kicks. This abusive tormenting is common amongst convicts. It is typical recreation for men with idle time to instigate fights in the prison yard. It is abusive when mentally ill prisoners, like him, are permitted to be used for such cruel sport. ${ }^{15}$ This is the kind of behaviour prison officials shield themselves from. When emotionally handicapped prisoners are goaded to act out or fight for the selfish amusement of convicts, this horrible spectacle is not only sad, but pathetic. Prisoners who must live under these conditions become withdrawn and bitter. Depression sets in. Emotionally fragile prisoners become, over time and exposure, emotionally ill themselves. ${ }^{16}$

Lately, this facility has seen an upturn in violence, drug trafficking, extortion, gang violence and other ills which affect prisons. Prisoners do not live in a vacuum; we live in constant sensory overload, an overwhelming environment where amusement is often at the expense of another's misery. This shodenfreud - taking an unnatural pleasure from the misery of others — fuels much of life behind bars.

MCI-Shirley faces many challenges. Today, correctional facilities must do double duty, bridging their mission to manage convicts with human services and the special needs of the criminally insane. The quest for sanity is expensive. Correctional facilities must be adequately funded to face $21^{\text {st }}$ century challenges. The Commonwealth and nation must revisit ideas about comprehensive health centres. New prison construction is advanced as a means to reduce dangerous overcrowding.

Today's opiate addiction crisis offers eerie similarities to this nation's war on crack-cocaine thirty years ago. In that wave, mass incarceration took hold. We live with the results. Heroin and illicit morphine based prescription abuse is this generation's next wave of prison expansion. Prisons like MCIShirley need resources. This institution is little more than an outlying island of social welfare adrift in a sea of social ill.

\section{ENDNOTES}

1 See: 18 F. Supp. 3d Cox V. Mass. Department of Corr. (March 12, 2014) Compare: Farmer v. Brennan, 511 U.S. 825 (1994): "Prison officials acted with deliberate indifference to prisoner health and safety". 
2 The Eighth Amendment to the U.S. Constitution states: “...that excessive bail is not to be required, nor excessive fines imposed, or cruel and unusual punishment inflicted". Similar to Massachusetts Constitution, Declaration of Rights art. 26, provides: "...no magistrate or court of law, is to demand excessive bail or sureties, impose excessive fines, or inflict cruel of unusual punishments".

3 To succeed on an Eighth Amendment claim, a plaintiff-prisoner must demonstrate that (1) a prison's condition's of confinement present "a substantial risk of serious harm" and (2) prison officials act with "deliberate indifference" to prisoner health and safety. See: Cox v. Mass Dep't of Corrections, 18 F. Supp. 3d (2014) Compare: Farmer v. Brennan, 511 U.S. 825 (1994).

4 Cox v. Mass. Department of Corrections, (supra). Compare: 2001 The Massachusetts Superior Court rules that residents at the "Treatment Centre" a part of Bridgewater State Hospital housing sex offenders "must be kept separate and part" from prisoners, "at all times" in accordance with state law. Durfee v. Maloney, Nos. CIV. A 982523B, and CIV. A 98-2082B, (2001) Mass. Super. LEXIS 253, 2001 WL 810385, at 15 Mass. Super. Ct. (July $16^{\text {th }} 2001$ ).

5 Ibid. It should be noted that the Massachusetts Sexually Dangerous Persons Law was passed in 1947, Mass. Gen. Laws Ch. 123A ***1, et. seq. The initial law was premised on the assumption that sex offending is caused by a severe mental illness which can be treated if the prisoner is given a one day to life commitment sentence at a mental health institution to participate in an intensive treatment regimen. By the end of the 1980's, the focus of treatment for sex offenders shifted. The Massachusetts Legislature in 1988 "concluded that the mental health approach to sex offender treatment was no longer effective because sexual violence is primarily a form of 'anti-social behaviour' which can be controlled but not "cured"'.

6 I first encountered the older prisoner at Billerica House of Detention where he was regularly removed to the solitary confinement unit. I witnessed him spitting at prisoners and spitting on the floor of his cell. He would yell from his cell all day and all night. He called the names of prisoners and staff asking loudly: "What's your name? Where you from?" He addresses prisoners and staff as "Asswipes".

7 MCI-Shirley encompasses two facilities housing both medium and minimum custody level prisoners. The majority of prisoners on 1 January 2014 were in medium security housing units $(1,139)$ with 202 housed in minimum security. The two security levels were considered separate institutions until 2002 when they were combined as one, operating under one administration (Massachusetts Department of Correction Population Trends 2013; Institution Overview, p.5).

8 During a 1989 Massachusetts government panel, a comprehensive mental health center was proposed, but never implemented. Governor's Special Advisory Panel on Forensic Mental Health (1989).

9 Dr. Kenneth Appelbaum, Chief Psychiatrist for the vendor, Massachusetts Correctional Health Services, testified of a "dire need" for a high security residential treatment facility as an alternative to segregation for prisoners with mental illnesses and that the number of mental-health clinicians was inadequate. The Department of Correction maintains it offers "adequate" protection to prisoners with mental illness. Ibid.

11 R. H. Mandeville v. Luis Spenser (July 2014). 
12 Ibid.

13 Ibid.

14 Massachusetts Gen. Law ch. $127 * * * 32$ requires prison officials to treat the prisoners with "the kindness which their obedience, industry, and good conduct merit". This requirement, however, extends only to "those inmates who are not being disciplined".

15 I witnessed the older prisoner being goaded by fellow prisoners. He was ultimately encouraged to verbally harass an even older convict many years in the system. The former verbally abused the latter, who slapped him in the face twice. This occurred on June $13^{\text {th }} 2015$ during late recreation in the yard in front of numerous other witnesses. The older prisoner who slapped him said: "I didn't want to punch him with a closed fist. I just slapped him to shut him up...but he's crazy and nothing will shut his mouth, not even if I beat his head in".

16 New England Journal on Criminal and Civil Confinement: Summer 2014 "The Movement Away From Solitary Confinement in the United States". "New York State on July 1, 2011 introduced the 'SHU Exclusion Law' mandating that prisoners with serious mental illness be diverted from solitary confinement units and instead be placed in residential mental health treatment units". "In Main, a Bill prohibits mentally ill prisoners from being placed in solitary confinement units". "There is little hope for those prisoners already suffering from mental illness to get better as the 'stress, lack of meaningful social contact, and unstructured days can exacerbate symptoms of illness, or provoke recurrence', etc".

\title{
REFERENCES
}

Calabresi, Massimo (2015) “The Price of Relief: Why America Can’t Kick Its Painkiller Problem", TIME Magazine - June 15.

\section{ABOUT THE AUTHOR}

Charles N. Diorio is a prisoner at MCI-Shirley and can be reached at the following addresses below:

\author{
Charles N. Diorio W103769 \\ P.O. Box 1218 \\ MCI-Shirley \\ Shirley, Massachusetts 01454 \\ USA
}

Attorney James J. Gavigan, Esq.

80 Billings Road

North Quinry, Massachusetts 02107

USA 